\title{
James (Jean/Jacques) Gardette (1756-1831)
}

\section{Xavier Riaud*}

History of Sciences and Technics, Laureate and Full member of the National Academy of Dental Surgery, Free member of the National Academy of Surgery, France

${ }^{\star}$ Corresponding Author: Xavier Riaud DDS, PhD in History of Sciences and Technics, Laureate and Full member of the National Academy of Dental Surgery, Free member of the National Academy of Surgery; 145, route de Vannes, 44800 Saint Herblain, France; Tel: +33240766488; E-mail: xavier.riaud@wanadoo.fr

Received: April 26, 2019; Accepted: May 07, 2019; Published: May 09, 2019;

James Gardette, Surgeon Dentist, was the second son of Jean Blaize Gardette, and was born 13th of August, 1756, in the town of Agen, departement de Lot et Garonne, France. His father died when James was quite a lad, and we are but little acquainted with this early period of his life : nor, indeed, does it enter into the plan for the performance of our task. We only know that he possessed a very trifling patrimony, insufficient for his maintenance or education, and that after his father's death he was brought up by his paternal uncle, Blaize Gardette, who lived at Agen, and held the office of Prosecuting Attorney until an advanced age. His uncle designed James for the medical profession, and with that view, after the ordinary academical studies of that day in a provincial town of France, sent him to Paris. He remained at the capital about two years (from 1773 to 1775), pursuing the study of Anatomy and Surgery in the Royal Medical School; and thence he was removed to the Hospital at Toulouse, where he resided eighteen months as a pupil in the Institution $[1 ; 5]$. At the end of this period he was sent to Bayonne, and there was examined by the surgeons of the Admiralty, and commissioned as a surgeon in the French navy. On obtaining the commission in the navy, he received orders to embark in his professional capacity, on board the brig of war La Barquaize de St. Jean de Luz, destined for Boston, Massachusetts. He sailed in October, 1777, with La Fayette and the Count of Rochambeau [1]. $\mathrm{He}$ arrived at Plymouth early in January following (1778). The love of liberty and popular movement throughout France, which brought so many young Frenchmen to the United States, at the period of our «Declaration of Independence,» had no small influence in governing the course of Gardette. He made a cruise of four months, during which an engagement occurred with two British ships, lasting three hours and a half, and in which there were several killed and wounded on board the vessel of which he was the surgeon. This seems to have terminated his official duties and connection with the French navy, from which he resigned, intending to adopt this country as his home. When the French fleet and army arrived at Newport (1780), he was induced to visit that town, and commence practice as a Dentist, the officers affording him considerable and congenial occupation for a short time. He had received instructions in dental operations (as part of his profession of Naval Surgeon) from Mrs. Le Roy de la Faudinière et Louis Laforgue, Dentists at Paris, then in high repute. He had also provided himself with the best works extant (Fauchard and Bourdet) on the Teeth, and with a limited set of dental instruments : still we scarcely think he could have had any expectations of pursuing the profession of Dentist in this country, at the time he left France [2].
In 1781-1782, he became acquainted with a young American soldier, Josiah Flagg (1763-1816), whom he is thought to have instructed in the art of French dentistry and became one of the most famous American dentist [3].

He returned to Boston from Newport, and in the autumn of 1783 we find, went to New York. He was there when the American army, under General Knox, took possession of the city - an inactive but not indifferent spectator of the great events of that interesting epoch in American history. His professional success as a Dentist in New York, seems to have been comparatively small, and his limited knowledge of the English language was, as yet, a great impediment to making himself known or appreciated as he desired. It was not until the summer of 1784, and in Philadelphia, that he attained the position which determined his permanent residence in the United States. The pleasant and successful character of his occupation among the best class of citizens in Philadelphia, at the period when Fourth Street was its western boundary, needs, perhaps, no stronger comment than the fact, that he continued there in uninterrupted practice as a Dentist, from 1784 to 1830 - a period of forty-six years!

In 1796, James Gardette made for George Washington a set of dentures from hippopotamus ivory [4]. When asked about the teeth, Gardette claimed it was "impossible to distinguish them from the natural ones " and that a person could " take them out and fix them again themselves with the greatest ease ». However, others disagreed, describing them as « too large and clumsy. » In 1859, Rembrandt Peale (1778-1860) stated that Gardette's dentures caused Washington's « mouth to be changed. » Stuart said that when he painted Washington, " he had just had a set of false teeth inserted, which accounts for the constrained expression so noticeable about the mouth and lower part of the face. " Regardless of the success of Washington's dentures, Gardette can be given credit for introducing the advanced techniques of Fauchard into American dentistry [3].

In 1808, he married Marie Julie Zulime Carriere (1781-1853) [3]. His education and manners as a gentleman - characteristics which, we may safely conclude, were not very commonly found among the soidisant Dentists of our country at that remote day. Gardette devoted himself attentively to the pursuit and improvement of his profession, and acquired no unenviable reputation for knowledge and skill in its various departments. The difficulties which the Dentist then had to contend with were manifold : he was dependent chiefly upon his own 
judgment and inventive genius for his success, and that too for the benefit of patients who, in many instances, had but little confidence in the operations of Dentistry. Instruments were the passing existence afforded by a newspaper, it had probably never claimed notice here, but been allowed all the honor that belongs to undeserved and uncontradicted misrepresentation [2]. Among the improvements introduced into the practice of Dental Surgery by Gardette, whether in the way of instruments or operations, some few, at least, have been identified with his name. «1822: To James Gardette, Dentist, for three mechanical improvements in his profession, highly commended in Europe and in the United States; and for a simple lever instrument for the easy and expeditious extraction of teeth and stumps of teeth - awarded, a medal ' to the most deserving,' and twenty dollars. " The above «award of merit» is the highest permitted by the will of John Scott, who left the fund for the objects specified. He was the first Dentist who substituted the use of elastic flat gold bands or braces, in the place of ligatures of silk or fine gold wire for securing artificial teeth, when attached to the living ones [5]. He invented the manner of mounting natural teeth, which consists of a gold mortise plate to which the teeth are secured by means of gold pins, and which permits the tooth to rest upon the gum instead of the gold plate [5]. He was the first to apply the principle of suction or atmospheric pressure for maintaining sets of artificial teeth for the upper jaw, as early as 1800 .

He secures artificial pieces without tying them, even when of limited extent. Laforgue said : "I have seen such, admirably secured, and am acquainted with no Dentist who equals him in this beautiful and valuable description of work. » Gardette related the following anecdote of port of entire sets of artificial teeth, dispensing with the use of spiral springs and the the chance which led to this important discovery. He had furnished, for the second time, an entire set of upper teeth (enamelled hipps) for Mrs. A. M'C, and owing to the short time the first set had lasted under the action of the saliva, he suggested that this set should be left much heavier. In order that the tongue should become accustomed to this increased bulk, necessarily contracting the limits for its free movements, the lady was desired to keep the new piece in her mouth as much as possible, during a few weeks, but not expecting her to use it for purposes of mastication or speech until the usual springs should be attached to it. Mr. G. promised, at the end of the period named, to call and arrange the piece for permanent use [5]. It was then still the custom for the Dentist to attend at the houses of his patients, and a busy season caused months instead of weeks to elapse, when Gardette called again: with an apology for neglect, his plyers and springs ready, he requested Mrs. M'C. to bring the artificial pieces. She replied, "I have them in my mouth, " much to the astonishment of her Dentist, with endless contrivances then in use, much to the inconvenience of those who wore them $[1 ; 3]$.

Nor were his improvements less important in the cure of diseases to which the teeth and gums are lia-ble : he was the early advocate, if not the first who recognized the wisdom, of affording space for the healthy and good arrangement of the teeth, by judicious extractions in youth. He believed, and his long experience proved, that he thus obviated a great cause of decay, arising from lateral pressure. She stated that at first they were a little troublesome, but she had become accustomed to them now, and they answered every purpose as well without as with springs, and she was glad to dispense with them. The principle upon which the artificial piece thus adhered to the gum at once suggested itself to his mind, and suction, or atmospheric pressure, was henceforth depended upon, in numerous cases of the same kind [2]. He was one of the earliest Dentists who adopted gold foil, instead of lead or tin, as the best material for filling teeth; and related often that he had at one period, prepared gold foil for his own use from Dutch ducats, when no gold-beater was to be found in this country, or none, at any rate, who could furnish Dentist's filling gold [2]. As an operator, Gardette displayed great judgment, care and dexterity, while he exhibited no misplaced or morbid sensibility inconsistent with the best performance of his painful professional duties.

In the mechanical departments of his art, his work evinced discrimination and good taste, as well as originality: his artificial pieces, at a period when no aid was to be derived from «Dental Laboratories,» possessed all the good workmanship and finish which are the result of mechanical skill and patient industry. His practice was characterized by the one strong motive of good to his patient, and not less by the liberal and benevolent feelings which should govern professional life [2]. His want of familiarity with the English language seems to have made him diffident about publishing his views or improvements in his profession; and it was not until 1827 that he was induced by his friend, the late Dr. James Mease, (a liberal and warm friend of the Arts and Sciences,) to furnish an article for the Medical Recorder on the "Transplantation of the Human Teeth", the first and the only publication that bears his name (seven pages published in January, 1827) [2]. As a practising Dentist, the usefulness of Gardette was much impaired during the latter years of his life by continued and severe suffering from the gout. He had long cherished a desire to return to France and end his days in his native country, but owing to unfortunate investments and various disappointments, this favorite plan was not accomplished until the year 1829, at the age of seventy-three, too late to realize the pleasant anticipations he had so long connected with such a step. His native village of Agen, which he revisited, was no longer what it had seemed to his longing heart, during an absence of half a century. He took up his residence at Bordeaux, where he died from an attack of gout, in August $1831[1 ; 5]$.

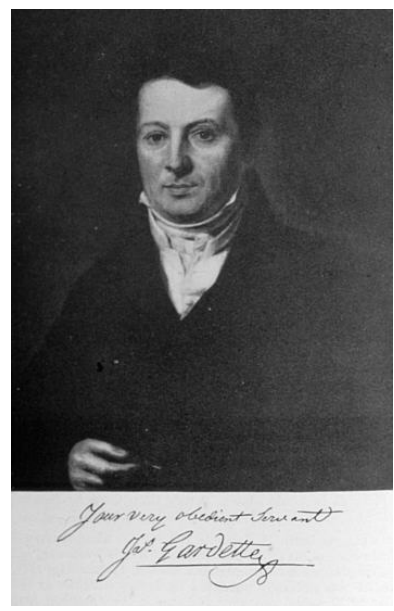

Jean Gardette (1756-1831) [3]. 


\section{References}

1. Rousseau C, « Histoire de l'aménagement opératoire du cabinet dentaire L'aménagement opératoire des dentistes des jeunes Etats américains ", in Actes de la Société française d'histoire de l'art dentaire, www.biusante.parisdescartes. $\mathrm{fr}$, sans date.

2. Gardette E (1847) Biographical notice of James Gardette, surgeon dentist of Philadelphia, Philadelphia Pg No: 1-22.

3. James "Jacques" Gardette (1756-1831) 2019. www.findagrave.com

4. Kandra G (2016) « The whole tooth », in CBSEveningNews,) Pg No: 1-2. https:// www.cbsnews.com

5. Laforgue L (1810) Théorie et Pratique de l'Art du Dentiste, Paris, pp. 20: 257-294. 